\title{
miRNAs and lncRNAs in Echinococcus and Echinococcosis
}

\author{
Zhi He ${ }^{1,+}$, Taiming Yan ${ }^{1}$, Ya Yuan ${ }^{1,2,+}$, Deying Yang ${ }^{1,2, *}$ and Guangyou Yang ${ }^{3} \mathbb{D}$ \\ 1 College of Animal Science and Technology, Sichuan Agricultural University, Chengdu 611130, \\ Sichuan, China; zhihe@sicau.edu.cn (Z.H.); yantaiming@sicau.edu.cn (T.Y.); yuanya145@hotmail.com (Y.Y.) \\ 2 Farm Animal Genetic Resources Exploration and Innovation Key Laboratory of Sichuan Province, \\ Sichuan Agricultural University, Chengdu 611130, Sichuan, China \\ 3 College of Veterinary Medicine, Sichuan Agricultural University, Chengdu 611130, Sichuan, China; \\ Guangyou1963@aliyun.com \\ * Correspondence: Deyingyang@sicau.edu.cn; Tel.: +86-028-8278-3043 \\ $\dagger$ These authors contributed equally to this work.
}

Received: 28 October 2019; Accepted: 19 January 2020; Published: 22 January 2020

check for updates

\begin{abstract}
Echinococcosis are considered to be potentially lethal zoonotic diseases that cause serious damage to hosts. The metacestode of Echinococcus multilocularis and E. granulosus can result in causing the alveolar and cystic echinococcoses, respectively. Recent studies have shown that non-coding RNAs are widely expressed in Echinococcus spp. and hosts. In this review, the two main types of non-coding RNAs-long non-coding RNAs (lncRNAs) and microRNAs (miRNAs) - and the wide-scale involvement of these molecules in these parasites and their hosts were discussed. The expression pattern of miRNAs in Echinococcus spp. is species- and developmental stage-specific. Furthermore, common miRNAs were detected in three Echinococcus spp. and their intermediate hosts. Here, we primarily focus on recent insights from transcriptome studies, the expression patterns of miRNAs and lncRNAs, and miRNA-related databases and techniques that are used to investigate miRNAs in Echinococcus and echinococcosis. This review provides new avenues for screening therapeutic and diagnostic markers.
\end{abstract}

Keywords: non-coding RNA; miRNA; lncRNA; Echinococcus; echinococcosis

\section{Introduction}

The metacestode form of Echinococcus spp. cestode parasites can result in the echinococcosis in the visceral organs (such as the liver and lung) of intermediate hosts. E. granulosus sensu lato (s.l.) and E. multilocularis are the two of the most common and researched harmful parasites [1]. Worldwide zoonoses are of great concern to public health; echinococcosis occurs worldwide and yet the amplitude of its severity is thought to be overlooked by the World Health Organization [1] and indeed occurs worldwide [2]. Cystic echinococcosis (CE) is typically the result of accidental ingestion of E. granulosus eggs and initiating detrimental effects to the liver and lungs [3] (Figure 1A). Mature adult E. granulosus tapeworms were found in the small intestine of the definitive host, a carnivore, are secreted in faecal matter releasing segments, or proglottids, comprised of large quantities of eggs, contaminating proximate vegetation and water sources. The larva then penetrate the intestinal wall of the intermediate hosts (such as sheep) and migrate through the circulation to various throughout the hosts body, in most cases, the liver and lungs. Whole cysts of E. granulosus are comprised of a cyst wall (CW) and hydatid cyst fluid. The brood capsules, protoscoleces, and free daughter cysts in hydatid cyst fluid are collectively referred to as hydatid sand [4]. Cystic echinococcosis can be characterised by the long-term growth of hydatid cysts in mammalian intermediate hosts and humans, imposing 
a substantial burden of disease and treatment. Alveolar echinococcosis is principally indicated by a tumour-like growth comprised of metacestodes in the rodents liver and, occasionally, human liver-caused by E. multilocularis [5,6] (Figure 1B). Adult worms of E. multilocularis living in the intestine of the host (e.g., foxes) are capable of producing vast quantities of eggs. Following the ingestion of contaminated liquids or food by small rodents, the eggs develop into metacestodes that predominantly encyst in the liver [7]. Subsequent ingestion of contaminated liquids or foods by small rodents develops metacestodes derived from the eggs, which produce large numbers of protoscoleces [7]. Though it is less frequent, occasionally humans ingest the eggs through contaminated food and water sources, mainly resulting in alveolar echinococcosis of the liver [8]. The current governmental measures implemented, although effective, cannot adequately eradicated alveolar echinococcosis and reliably control widespread E. multilocularis infection, particularly in some pastoral areas and mountainous in China $[9,10]$. Alveolar echinococcosis is considered to be one of the most dangerous parasite zoonoses to threaten humans in the world [7]. The prognosis and medical costs of patients largely depend on how early the infection of the parasite species is detected, the immune status of the individual, and the level of access to medical services [8]. Another Echinococcus species, E. canadensis, belongs to the E. granulosus sensu lato (s.l.) complex [11]. The metacestode of E. canadensis is characterised by the presence of a combination of key structures, such as an unilocular fluid-filled cyst, being identifiable by its cyst wall. Consisting of an inner germinal layer and an outer acellular laminated layer, surrounded by host-originated adventitial layer [12]. The small immature worms and protoscoleces are developed from the germinal layer of the cyst wall [12]. The intermediate host of E. canadensis is predominantly ungulates, however, occasionally, it can be humans [12].

The major portion of a given genome is transcribed as non-coding RNAs [13]. The genomes of Echinococcus spp. have similar characteristics; approximately $10-14 \%$ of the genome constitutes protein-coding genes, while the remaining genes are transcribed as non-coding RNAs [14,15]. Non-coding RNAs can be classified into two types, according to their molecular weight. Short RNAs, such as microRNAs (miRNAs, 18 24 nucleotides (nt)), are $<200 \mathrm{nt}$ in length. Long non-coding RNAs (lncRNAs) are longer than $200 \mathrm{nt}$ and they contain long non-coding RNAs (lncRNAs) and circular RNAs (circRNAs) [13,16] (Figure 1C). Previous studies have reported that non-coding RNAs play important roles in physiological and pathological processes in eukaryotes [17]. MiRNAs and lncRNAs are widely expressed in Echinococcus spp., such as E. granulosus, E. multilocularis, and E. canadensis [18,19]. MiRNAs are small, yet powerful, regulatory RNAs that are implicated in the post-transcriptional regulation of almost all the cellular signaling pathways in both the animals and plants [20]. The seed sequence of mature miRNAs, which is 2 7 nt long, has been identified as the most essential region for the recognition of target mRNAs, IncRNAs, and circRNAs through base pair complementarity [21,22] (Figure 2). An increasing number of miRNAs that are widely expressed in Echinococcus spp. have been identified [23]. The parasite's autologous proteins and miRNAs transferred to host cells, where they undergo adaptations to produce parasitic forms, when parasitic helminths reach the gut $[6,24,25]$. Thus, miRNAs may be key regulatory factors that are involved in the helminth-host interaction [26]. The transcription of intergenic miRNAs depends on the favouring of the original genes over expanding targets in different cell types, tissues, developmental stages, and is one of the main biofunctional pathways in parasites. These observations suggest that miRNAs are important in Echinococcus spp. and echinococcosis and, thus, may serve as diagnostic or treatment targets.

LncRNAs are longer than $200 \mathrm{nt}$ and they have lower levels of sequence conservation and expression than protein-coding genes do with an mRNA-like structure, and some have a poly(A) tail [27]. The mechanism of action of lncRNAs is very complex [28] and it is still not entirely understood within the scientific community. Therefore, to date, the lncRNA profile of Echinococcus spp. has not yet been reported. However, IncRNA patterns have been described in several the intermediate hosts, such as sheep [29], goats [30], cattle [31], swine [32], horses [33], and humans [34], and the definitive host, canines [35]. LncRNAs were identified as an important regulatory factor that is crucial in regulating immunological stress during cystic echinococcosis, in an experimental mouse model of 
cystic echinococcosis [19]. In addition, IncRNAs have also been identified as important in the biological functions of other parasites (e.g., Trichomonas vaginalis [36] and Toxoplasma [37]) and in host immunity. Thus, we speculate that lncRNAs may be expressed in Echinococcus spp. and perform large-scale biological functions in both parasites and hosts.

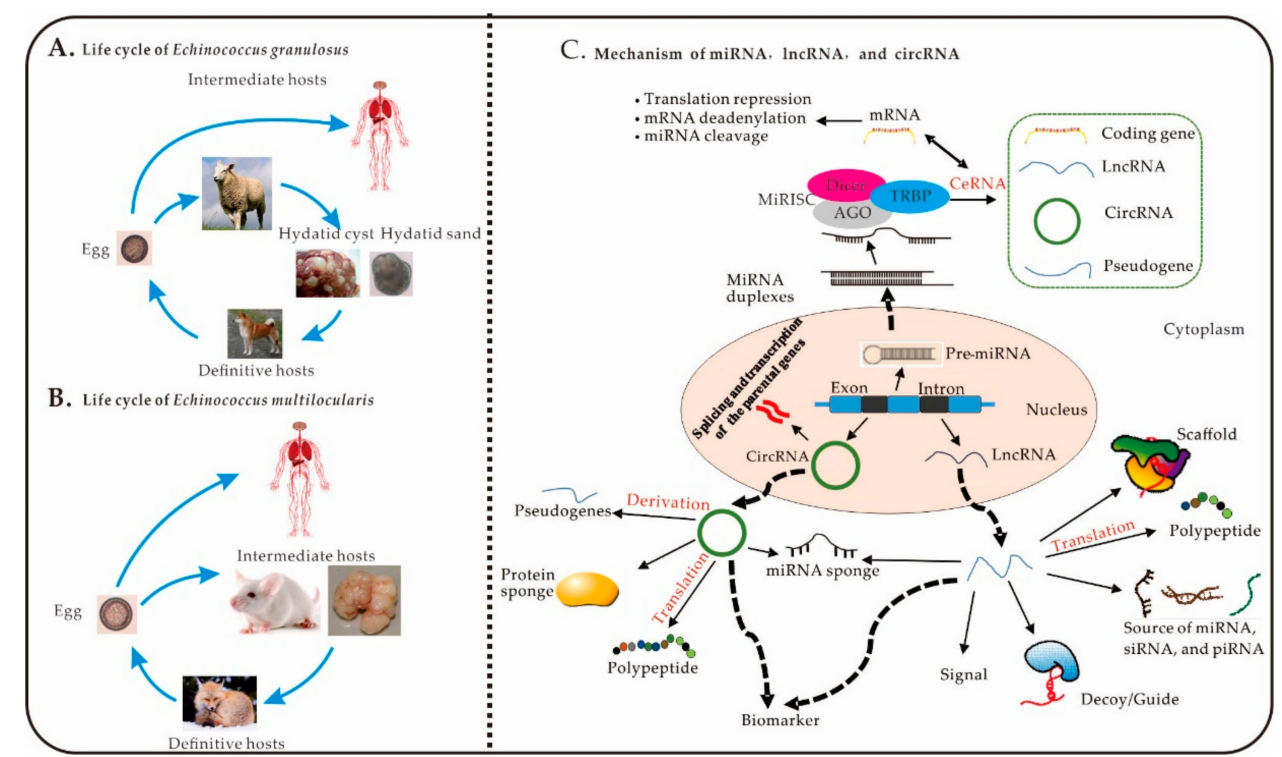

Figure 1. The life cycle of Echinococcus spp. and mechanisms of miRNAs, IncRNAs, and circRNAs. (A), Life cycle of E. granulosus. (B), Life cycle of E. multilocularis. (C) Mechanisms of miRNAs, lncRNAs, and circRNAs: (1) MiRNA: pre-miRNA is transcribed from genomic DNA with a double-stranded RNA hairpin and a stem-loop structure in the nucleus [38,39]. The mature miRNA can be loaded into the RNA-induced silencing complex (RISC), resulting of miRNA, Dicer, the RNA-binding protein Argonaute (AGO), and the adaptor protein TAR-RNA-binding protein (TRBP) [40]. The complementary sequences in the untranslated regions of lncRNAs, mRNAs, circRNAs, and pseudogenes can competitively bind to miRNAs, which results in translational repression and degradation of mRNA and miRNA cleavage. (2) CircRNA: circRNAs are spliced and transcribed from genomic DNA and transported to the cytoplasm to perform numerous biological functions. One example of such functions is the translation of derived pseudogenes, sponge proteins and miRNAs, into polypeptides [41]. (3) LncRNA: lncRNAs play important biological roles in the cytoplasm; including acting as signalling molecules, decoys, guides, and scaffolds; being translated into polypeptides, and serving as sources of small interfering RNAs (siRNAs), miRNAs, and Piwi-interacting RNAs (piRNAs) [42].

\section{Widespread Expression of miRNAs in Echinococcus spp. According to Transcriptome Analysis}

Large miRNAs, being identified in E. granulosus, E. multilocularis, and E. canadensis (G7), have been found to feature certain characteristics of genes in expression regulation, such as tissue and developmental stage specificity, in their respective hosts $[18,19,43]$. To date, the miRNA expression profiles of E. granulosus sensu stricto (76 known miRNAs, including adults, cysts, and protoscoleces) [44,45], E. canadensis (46 known miRNAs, including cysts and protoscoleces) [12,46], and E. multilocularis (46 known miRNAs, including cysts) [1] have been reported (Table 1). Mature miRNAs and pre-miRNA sequences in E. canadensis (G7) and E multilocularis share an average sequence identity of $98.4 \%$ and $99.1 \%$, respectively [1]. Furthermore, miRNAs share $\geq 87 \%$ identity between E. granulosus sensu stricto and E. multilocularis [44]. However, 22 conserved miRNA families (involved in ciliated cells, the gut, and sensory organs) are not detectable in E. granulosus [44]. 
Table 1. Widespread Expression of microRNAs (miRNAs) in Echinococcus spp. According to Transcriptome Analysis.

\begin{tabular}{|c|c|c|c|c|c|c|c|c|}
\hline Species & Tissue & Source & Genotype & Clean Reads & Identified miRNAs & Technology & Country & Ref. \\
\hline \multirow{11}{*}{ E. granulosus } & Protoscoleces & $\begin{array}{l}\text { Porcine liver hydatid } \\
\text { cysts and bovine lung } \\
\text { hydatid cysts }\end{array}$ & G1 & \multirow{6}{*}{182} & $\begin{array}{l}34 \text { conserved and four new } \\
\text { candidate miRNAs }\end{array}$ & \multirow{6}{*}{ Sanger } & \multirow{6}{*}{$\begin{array}{l}\text { Argentina and } \\
\text { Uruguay }\end{array}$} & \multirow{6}{*}{45} \\
\hline & Protoscoleces & Pig & G7 & & $\begin{array}{c}\text { miR-125, miR-2, miR-71, miR-9, } \\
\text { miR-10, let-7 and miR-277 }\end{array}$ & & & \\
\hline & Protoscoleces & Sheep & G1 & & $\begin{array}{l}\text { miR-125, miR-2, miR-71, miR-9, } \\
\text { miR-10, let-7 and miR-277 }\end{array}$ & & & \\
\hline & $\begin{array}{c}\text { Germinal layer of } \\
\text { secondary cysts }\end{array}$ & Murine & G1 & & $\begin{array}{l}\text { miR-2, miR-71, miR-9, miR-10, } \\
\text { let-7 and miR-277 }\end{array}$ & & & \\
\hline & Pre-microcysts & $\begin{array}{l}\text { Porcine liver and } \\
\text { bovine lung }\end{array}$ & G7 & & miR-125, miR-2 & & & \\
\hline & Microcysts & $\begin{array}{l}\text { Porcine liver and } \\
\text { bovine lung }\end{array}$ & G7 & & miR-71 & & & \\
\hline & Protoscoleces & Sheep liver & - & $21,708,040$ & $\begin{array}{c}109 \text { known and } 260 \text { novel } \\
\text { miRNAs }\end{array}$ & $\begin{array}{l}\text { Illumina HiSeq }^{\mathrm{TM}} \\
250\end{array}$ & China & [47] \\
\hline & Adult & Sheep liver hydatid cysts & \multirow{3}{*}{-} & $10,069,724$ & $\begin{array}{c}46 \text { known miRNAs, } 92 \text { novel } \\
\text { mature miRNAs }\end{array}$ & \multirow{3}{*}{$\begin{array}{l}\text { Illumina Genome } \\
\text { Analyzer II }\end{array}$} & \multirow{3}{*}{ China } & \multirow{3}{*}{44} \\
\hline & Protoscoleces & Sheep liver & & $11,775,532$ & $\begin{array}{c}45 \text { known miRNAs, } 91 \text { novel } \\
\text { mature miRNAs }\end{array}$ & & & \\
\hline & Cyst membrane & Dog & & $8,025,262$ & $\begin{array}{c}45 \text { known miRNAs, } 103 \text { novel } \\
\text { mature miRNAs }\end{array}$ & & & \\
\hline & Protoscoleces & $\begin{array}{l}\text { Naturally infected } \\
\text { sheep liver }\end{array}$ & G1 & $\begin{array}{c}\text { 1,642,112/1,956,161 (two } \\
\text { biological replicates) }\end{array}$ & 36 miRNAs & $\begin{array}{l}\text { Illumina Genome } \\
\text { Analyzer II }\end{array}$ & China & [12] \\
\hline \multirow{3}{*}{ E. canadensis } & Protoscoleces & \multirow{2}{*}{$\begin{array}{l}\text { Naturally infected } \\
\text { swine liver }\end{array}$} & \multirow{3}{*}{ G7 } & $\begin{array}{c}4,065,356 / 1,882,945 \text { (two } \\
\text { biological replicates) }\end{array}$ & 35 miRNAs & \multirow{3}{*}{$\begin{array}{l}\text { Illumina Genome } \\
\text { Analyzer II }\end{array}$} & \multirow{3}{*}{ China } & \multirow{3}{*}{12} \\
\hline & Cyst walls & & & $\begin{array}{c}\text { 2,487,372/2,117,367 (two } \\
\text { biological replicates) }\end{array}$ & 35 miRNAs & & & \\
\hline & Cyst walls & Swine liver & & $\begin{array}{c}\text { 16,431,381/16,364,826 (two } \\
\text { biological replicates) }\end{array}$ & 42 miRNAs & & & \\
\hline \multirow[b]{2}{*}{ E. multilocularis } & Metacestodes & $\begin{array}{l}\text { Female CF1 mice } \\
\text { (6-8 weeks old) }\end{array}$ & - & $\begin{array}{c}24,703,158 / 20,396,074 \text { (two } \\
\text { biological replicates) }\end{array}$ & 37 miRNAs & $\begin{array}{l}\text { High-throughput } \\
\text { small RNA } \\
\text { sequencing }\end{array}$ & Argentina & [1] \\
\hline & Metacestodes & $\begin{array}{l}\text { Naturally infected } \\
\text { crab-eating macaque } \\
\text { (Macaca fascicularis) liver }\end{array}$ & - & $\begin{array}{c}\text { The complete } E \text {. } \\
\text { multilocularis genome } \\
\text { (https://www.genedb.org/ } \\
\text { \#/species/Emultilocularis) }\end{array}$ & 24 miRNAs & $\begin{array}{c}\text { Self-organizing map } \\
\text { analysis }\end{array}$ & $\begin{array}{l}\text { Northern } \\
\text { Germany }\end{array}$ & [46] \\
\hline
\end{tabular}

Note: "—" means that the genotype was not mentioned in the relevant references. 


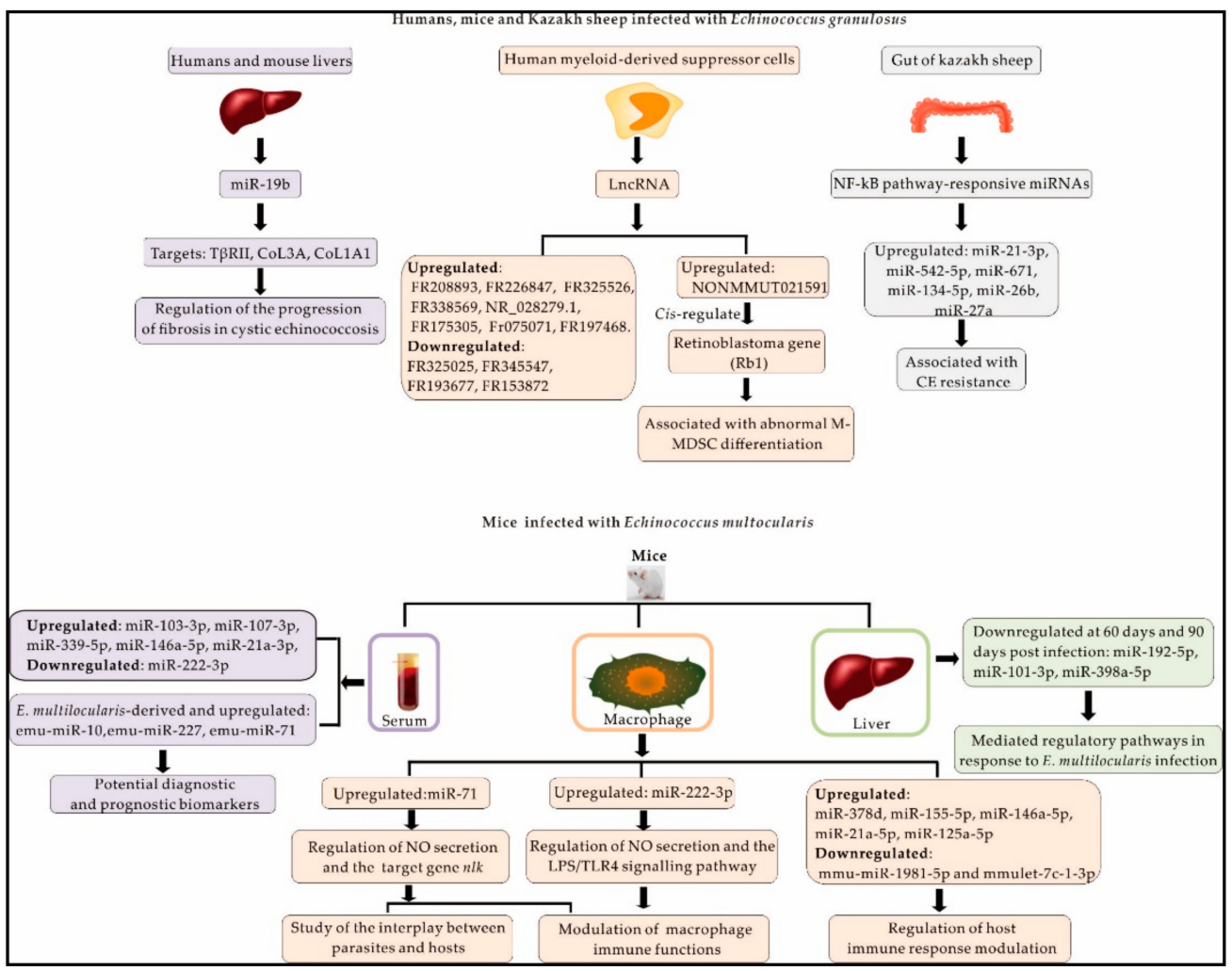

Figure 2. Non-coding RNAs involved in the intermediate host response to Echinococcus spp.

\subsection{MiRNAs Expressed in Different Developmental Stages of E. granulosus Sensu Stricto}

MiR-2, miR-71, and miR-125 have the highest expression levels among the 76 known miRNAs of E. granulosus sensu stricto $[44,45]$. Interestingly, the expression levels of miR-124b* and miR-87* are higher than those of their mature miRNAs, which suggests that they act as effectors during development and derivatives of their corresponding pre-miRNAs produce two different regulatory small RNAs [45]. In addition, miRNAs were found to exhibit tissue- and phase-specific expression [45]. MiR-277, let-7, miR-71, miR-10, miR-2, and miR-9 are specifically expressed in the cysts walls of secondary hydatid cyst and protoscoleces of G1 and G7 genotype, whereas miR-125 is only detected in protoscoleces and pre-microcysts. Additionally, three miRNAs (let-7, miR-71, and miR-2) are expressed at high levels in protoscoleces of metacestodes (cyst walls), which suggests that their expression is developmentally regulated [45]. Gene Ontology (GO) enrichment analysis revealed that the differentially expressed miRNAs in E. granulosus and their potential targets may participate in nutrient metabolism and bi-directional development of the nervous system [44].

\subsection{MiRNA Expression Profiles in E. canadensis}

Among E. canadensis G7 miRNAs, bantam, miR-281, miR-184, miR-3479, miR-61, and miR-new-3 have been verified to be expressed in cyst walls G7 (CWG7) and protoscoleces G7 (PSG7) [12]. MiR-71 and let-7 are the most abundantly miRNAs expressed, accounting for $50 \%$ of total miRNA expression in two stages that are essential for Echinococcus survival in the intermediate host. Moreover, miR-4989 is verified as one of the most abounding miRNAs expressed in cyst wall tissues [12]. Fifteen miRNAs are differentially expressed between the cyst walls and protoscolex of E. canadensis G7 (miR-219-5p, miR-4989-3p, miR-27-3p, miR-190-5p, and miR-61-3p are downregulated in CWG7; miR-8-3p, miR-133-3p, miR-96-5p, miR-281-3p, miR-124b-3p, miR-7a-5p, miR-124a-3p, miR-7b-5p, miR-153-5p, and miR-125-5p are upregulated in PSG7) and may be integral to the maintenance of stage-specific features [12]. MiR-4989 and miR-277 may share the same seed region, which suggests that they may also share some target genes that are involved in the preservation of germinal 
layer features [12,24]. MiR-125 is the most highly upregulated miRNA in PS. Each miRNA family of E. canadensis had varied quantities of targets of, for example, miR-2 (miR-2b/2c) and miR-71 families [45]. GO enrichment analysis revealed that potential miRNA targets in E. canadensis are involved in protein phosphorylation, transmembrane transport, and transcription regulation. Target genes participate in the Wnt signalling pathway, endocytosis, and the mitogen-activated protein kinase (MAPK) signalling pathway, according to the Genomes (KEGG) enrichment and Kyoto Encyclopedia of Genes analysis [23].

\subsection{MiRNA Expression Patterns in E. multilocularis}

Of the 46 mature miRNAs in E. multilocularis that were identified by high-throughput sequencing, five miRNAs, let-7, miR-10, bantam, miR-71, and miR-9 were the most highly expressed miRNAs in E. multilocularis [1]. MiR-31-3p and miR-31-5p were only detected in E. multilocularis datasets and not E. canadensis (G7) datasets. Some miRNAs, such as miR-96, miR-190, miR-3479b, and miR-184, are intronic pre-miRNAs. In other cases, uridylation of Echinococcus miRNAs is common (e.g., miR-9-5p, miR-3479b-3p, and miR-71), and the isomer-U is abundant in E. multilocularis [1]. Kamenetzky et al. (2016) reanalysed the miRNA profile based on E. multilocularis genome-wide data while using an algorithm (deep architecture) of self-organizing maps (SOMs) [46], from this three new miRNAs were predicted: emu_miR-new2-3p, emu_miR-new3-5p, and emu-miR-new9-3p. Interestingly, the authors discovered miRNAs in E. multilocularis that were not identified with the Megablast algorithm (i.e., miR-3479, miR-307, miR-36, and miR-1992) [48].

\subsection{Common miRNAs in Echinococcus spp.}

In this review, all of the identified miRNAs in E. granulosus sensu stricto, E. multilocularis and E. canadensis (G7) were obtained from the reported articles $[1,12,44-46]$. Across the three species analysed, some miRNAs were shown to be highly conserved, which suggested further functional conservation. Eighty-seven miRNAs, suggesting highly conserved miRNAs may perform crucial roles in the development and parasitism of Echinococcus spp. Among these highly conserved miRNAs; miR-71, bantam, let-7, miR-9, miR-10, miR-7, miR-87, and miR-61 were the most highly expressed miRNAs in E. multilocularis and E. Canadensis (G7) infection of the intermediate host $[1,12,44]$. The function of the miRNAs miR-71, let-7, and miR-61 were verified [44,49], and the target of miR-71 was also confirmed (Table 2), in total, the targets and biological functions of fifteen miRNAs in Echinococcus were predicted. The miRNA let-7 exhibited a substantially increased expression in protoscoleces and cysts, which might be associated with the bi-directional development capabilities of E. granulosus [44]. Moreover, Mortezaei et al. demonstrated that, under benzimidazole exposure in vitro, the expression of E. granulosus miRNAs let-7 and miR-61 was significantly affected in the microcyst stage; however, these miRNAs exhibited different alteration patterns in response to albendazole sulfoxide in other developmental stages [49]. In addition, the ubiquitin-conjugating enzyme E2 was identified as the potential target of miR-307, suggesting that miR-307 might be involved in ubiquitin-mediated proteolysis and herpes simplex infection signalling pathways in Echinococcus [23].

MiRNAs highly expressed in Echinococcus, but not expressed in vertebrate host, may have diverged from their host homologue miRNAs, for instance, bantam, miR-71, and miR-277 [12], can be assessed as candidate targets for diagnostic markers and intervention strategies. A previous study found that nematode exosome-derived miR-71 plays an important role interaction between the host and parasite, as an innate immune regulator [50,51]. A mimic of Echinococcus-derived miR-71 did not change the level of IL-10 in mouse RAW264.7 cells to evade host immune surveillance [52,53]. Furthermore, it can also be deduced that miR-277 might be involved in regulating Wnt signalling pathways, which are responsible for the regulation of stem cell pluripotency in Echinococcus [23]. The conservation of miRNAs that are involved in Echinococcus regulation reflects the complex and sophisticated adaptations, which are necessary for different environments, present within the life cycles of parasitic species. 
Table 2. Common miRNAs in Echinococcus spp.

\begin{tabular}{|c|c|c|c|}
\hline MiRNA & Description of Target Genes & Biological Function & \\
\hline MiR-71 & Nemo-like kinase & $\begin{array}{l}\text { Involved in protoscolex development and regulates } \\
\text { host macrophage functions in Echinococcus }\end{array}$ & {$[52,54]$} \\
\hline Let-7 & Unknown & $\begin{array}{l}\text { May be associated with the capability of E. granulosus } \\
\text { for bi-directional development, can be significantly } \\
\text { affected in the microcyst stage of } E \text {. granulosus and } \\
\text { can exhibit different changes in expression in } \\
\text { response to albendazole sulfoxide }\end{array}$ & {$[44,49]$} \\
\hline MiR-61 & Unknown & $\begin{array}{l}\text { Significantly affected in the microcyst stage of } E \text {. } \\
\text { granulosus and exhibits different changes in } \\
\text { expression in response to albendazole sulfoxide }\end{array}$ & [49] \\
\hline MiR-10 & $\begin{array}{c}\text { MAPKs; ECANG7_04447; } \\
\text { ECANG7_01705; ECANG7_09658 }\end{array}$ & $\begin{array}{l}\text { May be involved in regulating the MAPK and Wnt } \\
\text { signalling pathways in Echinococcus }\end{array}$ & [23] \\
\hline MiR-124 & $\begin{array}{c}\text { ECANG7_04102; ECANG7_10164; } \\
\text { ECANG7_00514; ECANG7_02390; } \\
\text { ECANG7_01054 }\end{array}$ & $\begin{array}{l}\text { May regulate development, host-parasite } \\
\text { interactions, and stem cell pluripotency; related to } \\
\text { the MAPK and TGF-beta signalling pathways } \\
\text { in Echinococcus }\end{array}$ & [23] \\
\hline MiR-184 & $\begin{array}{c}\text { ECANG7_02390; ECANG7_09002 } \\
\text { (casein kinase II); ECANG7_05735 } \\
\text { (phosphatidylinositol } \\
\text { phospholipase C gene); } \\
\text { ECANG7_00867 } \\
\text { (calcium/calmodulin-dependent } \\
\text { protein kinase gene) }\end{array}$ & $\begin{array}{l}\text { May act in a regulatory loop in miRNA biogenesis } \\
\text { in Echinococcus }\end{array}$ & [23] \\
\hline MiR-277 & ECANG7_01278; ECANG7_02522 & $\begin{array}{l}\text { May be involved in the regulation of Wnt signalling } \\
\text { pathways regulating the pluripotency of stem cells } \\
\text { in Echinococcus }\end{array}$ & [23] \\
\hline MiR-281 & $\begin{array}{c}\text { ECANG7_04919 and } \\
\text { ECANG7_00818 (glypicas); Nos-1 }\end{array}$ & $\begin{array}{l}\text { Potentially involved in the developmental } \\
\text { morphogenesis of Echinococcus. }\end{array}$ & [23] \\
\hline MiR-2 & $\begin{array}{l}\text { ECANG7_10172; ECANG7_02390; } \\
\text { Nos-1; ECANG7_02601; } \\
\text { ECANG7_05326 }\end{array}$ & $\begin{array}{l}\text { Potentially involved in ubiquitin-mediated } \\
\text { proteolysis and herpes simplex infection signalling } \\
\text { pathways, TAFH/NHR1 transcription initiation, and } \\
\text { segmentation in Echinococcus }\end{array}$ & [23] \\
\hline MiR-307 & Ubiquitin-conjugating enzyme, E2 & $\begin{array}{l}\text { May be involved in the ubiquitin-mediated } \\
\text { proteolysis and herpes simplex infection signalling } \\
\text { pathways in Echinococcus }\end{array}$ & [23] \\
\hline MiR-7 & $\begin{array}{c}\text { ECANG7_04919 and } \\
\text { ECANG7_00818; ECANG7_03238 }\end{array}$ & $\begin{array}{l}\text { Potentially involved in the developmental } \\
\text { morphogenesis of Echinococcus }\end{array}$ & [23] \\
\hline MiR-9 & ECANG7_02182; ECANG7_05944 & $\begin{array}{c}\text { Bromodomain-containing protein is an orthologue of } \\
\text { Caenorhabditis elegans lin- } 49 \text {, which is involved in } \\
\text { nematode larval development }\end{array}$ & [23] \\
\hline MiR-96 & ECANG7_06901 & $\begin{array}{l}\text { Unknown, but has a high level of expression, } \\
\text { particularly in the Echinococcus protoscolex stage. }\end{array}$ & [23] \\
\hline MiR-125 & ECANG7_01292; ECANG7_01524 & May regulate developmental genes in Echinococcus & [23] \\
\hline MiR-36 & Unknown & $\begin{array}{l}\text { May correspond with the increased regenerative } \\
\text { capacity of E. multilocularis with respect to that of } \\
\text { E. granulosus s.l. }\end{array}$ & [1] \\
\hline MiR-745 & $\begin{array}{l}\text { G2:M phase-specific E3 ubiquitin } \\
\text { protein ligase }\end{array}$ & Unknown & [23] \\
\hline MiR-8 & $\begin{array}{l}\text { Occludin/RNA polymerase II } \\
\text { elongation factor, ELL domain RNA } \\
\text { polymerase II elongation factor ELL }\end{array}$ & Unknown & {$[23]$} \\
\hline MiR-87 & Zinc finger, $\mathrm{C} 2 \mathrm{H} 2$ & Unknown & [23] \\
\hline Bantam & Ribosomal protein S2 & Unknown & {$[23]$} \\
\hline
\end{tabular}




\section{Non-Coding RNAs in Intermediate Hosts during Infection with Echinococcus spp.}

High-throughput sequencing and miRNA microarray analyses identified dysregulated miRNAs present during parasite infection in natural hosts and animal models that were present in relevant cells, tissues, and blood; demonstrating the importance of these miRNAs in host responses to pathogen challenges $[19,43,55]$. Recent research results have shown that circulating non-coding RNAs, including miRNAs and lncRNAs, can be stably detected in the blood of hosts that were infected with E. granulosus and E. multilocularis $[19,43,56]$ (Table 3). These stably circulating non-coding RNAs have the potential to provide us with an understanding of their roles in the host-parasite interaction, development, and growth; and, could potentially serve as diagnostic targets and therapeutic candidates.

\subsection{MiRNAs and lncRNAs in Host Responses to E. granulosus}

MiRNA and lncRNA profiles change when hosts are infected with E. granulosus (Figure 2). The gut of the intermediate host is integral to the process, as the first effector of host defence against Echinococcus spp. Sheep are highly susceptible to cystic echinococcosis as intermediate hosts. NF- $\mathrm{KB}$ pathway-responsive miRNAs, which are related to the inflammation process, are expressed in significantly higher proportions in CE-resistant sheep than in non-CE-resistant sheep, specifically miR-27a, miR-542-5p, miR-134-5p, miR-21-3p, miR-26b, and miR-671 [57] (Figure 2). It could therefore be concluded from aforementioned results that the differential expression of miRNAs present in CE-resistant and non-CE-resistant sheep may be key in the response of intestinal tissues to E. granulosus. Myeloid-derived suppressor cells (MDSCs), which are a heterogeneous population of myeloid cells, are composed of dendritic cells, granulocytes, and terminally differentiated macrophages; parasitic infection results in aberrant MDSC expansion [58]. MDSCs accumulate to high levels in mouse models $[19,59]$ and they have demonstrated an important function in the down regulation of the immune response of T lymphocytes when infected with E. granulosus protoscoleces. Several differentially expressed lncRNAs and mRNAs were identified between the normal mice and splenic monocytic MDSCs of E. granulosus protoscoleces-infected mice [19] (Figure 2). KEGG pathway enrichment analysis suggests that the lncRNAs co-expressed with mRNAs are mainly primarily involved in regulating the vascular endothelial growth factor (VEGF) signalling pathway, the leishmaniasis, Salmonella infection, and actin cytoskeleton [19]. The results showed that the aforementioned transcription factors are known to regulate lncRNA production, several of the most likely transcription factors (PGR, IL6, YY1, and FOSL1) for those lncRNAs were predicted by lncRNA-target-transcription factor network analysis [19]. These transcription factors mainly regulate the lncRNAs FR049933, FR291292, FR110455, and FR400826 and they participate in the MAPK and VEGF signalling pathways that are involved in MDSC function [19]. Specifically, the retinoblastoma gene Rb1, the expression of which is associated with abnormal M-MDSC differentiation, and was cis-regulated by the lncRNA NONMMUT021591 [19]. Such results show that lncRNAs participate in the immune regulation of the intermediate host, mice, in their defence against E. granulosus, and might be useful as specific biomarkers for CE.

\subsection{Mouse miRNAs Dysregulated during Infection with E. multilocularis}

The miRNA expression levels of mice were found to significantly in the sera and livers from mice in different stages of E. multilocularis infection [43,60] (Figure 2). Mmu-miR-146a-5p, mmu-miR-107-3p, mmu-miR-103-3p, and mmu-miR-21a-3p were found to be significantly upregulated after four weeks of infection. Furthermore, the expression of mmu-miR-339-5p was significantly upregulated at four weeks post-infection, but did not differ from baseline at eight or 12 weeks post-infection. In contrast, mmu-miR-222-3p was found to be significantly downregulated throughout the process of infection. The infectious stage of E. multilocularis can be estimated by the expression levels of these miRNAs. The GO terms enriched in potential miRNA targets are involved in the metabolism, signal transduction, immune response, and gene expression regulation [43]. Among E. multilocularis-derived circulating miRNAs, only emu-miR-10, emu-miR-227, and emu-miR-71 have been verified [43]. 
These E. multilocularis-derived circulating miRNAs may be used as potential diagnostic markers in intermediate hosts. The levels of three miRNAs (mmu-miR-378a-3p, mmu-miR-101b-3p, and mmu-miR-192-5p) were significantly decreased 90 days post-inoculation when compared to 30 days post-inoculation in mouse livers [60]. These results can inform further studies of the role of host miRNAs during E. multilocularis infection.

\subsection{Common miRNA Families in the Host Model during Infection with Echinococcus spp.}

All of the identified miRNAs in the sheep gut and in mouse macrophages, livers, and sera were collected from published literature $[43,57,60]$. The confirmed miRNA families were then classified according to their annotations in these articles $[43,57,60]$. Twenty-two common miRNA families were distinguished in intermediate hosts (including sheep and mice) during infection with Echinococcus spp. (Table 3), all of which were upregulated in the sheep gut and showed differential expression levels in mouse macrophages, livers, and sera. MiRNAs (e.g., miR-181 [61], miR-30 [62], miR-365 [63], miR-378 [64], miR-449 [65], miR-99 [66], miR-130 [67], and miR-16 [68]) have multiple target genes, including mRNAs, lncRNAs, and circRNAs; this may be key in determining the common miRNAs involved in the hosts response to infection with Echinococcus spp., which exhibit different expression levels, functions, and targets in host sheep and mouse models. Many miRNAs, such as miR-181 [57], miR-21 [69], and miR-27 [70], were implemented in the regulation of the immune response in intermediate hosts that were infected with Echinococcus spp. Further research should focus on the functional mechanisms of these common miRNAs in hosts that were infected with Echinococcus spp. and their potential roles in the treatment of echinococcosis. 
Table 3. Common miRNA Families in Intermediate Hosts during Infection with E. granulosus, E. multilocularis, and E. canadensis.

\begin{tabular}{|c|c|c|c|c|c|c|c|}
\hline \multirow{3}{*}{ MiRNA } & \multicolumn{4}{|c|}{ Expression Level } & \multirow{3}{*}{ Target } & \multirow{3}{*}{ Biological Function } & \multirow{3}{*}{ Ref. } \\
\hline & \multirow{2}{*}{ Sheep Gut } & \multicolumn{3}{|c|}{ Mouse } & & & \\
\hline & & Macrophage & Liver & Serum & & & \\
\hline MiR-1247 & $\uparrow$ & - & - & $\downarrow$ & CircUBXN7 & Represses cell growth and invasion in human bladder cancer. & [71] \\
\hline MiR-145 & $\uparrow$ & - & $\downarrow$ & - & ZEB2 & $\begin{array}{l}\text { Increases the apoptosis of activated hepatic stellate cells induced by TRAIL via the NF-kB } \\
\text { signalling pathway. }\end{array}$ & [72] \\
\hline MiR-181 & $\uparrow$ & - & - & $\downarrow$ & $\begin{array}{c}\text { Smad7 } \\
\text { Hsa_circ_0007385 }\end{array}$ & $\begin{array}{l}\text { Influences the differentiation of Thelper cells and the activation of macrophages, controls } \\
\text { T cell sensitivity to antigens during development }\end{array}$ & [73] \\
\hline MiR-18 & $\uparrow$ & - & - & $\uparrow$ & Unknown & $\begin{array}{l}\text { As the female immunity regulator, miR-18 controls the expression of A20/Tnfaip3 and } \\
\text { exacerbating NF-kB-driven inflammation in fibroblast-like synoviocytes of } \\
\text { rheumatoid arthritis }\end{array}$ & [74] \\
\hline MiR-20 & $\uparrow$ & - & $\downarrow$ & - & ATG10 & $\begin{array}{l}\text { Inhibits autophagy and chondrocyte proliferation by targeting ATG10 through the } \\
\text { PI3K/AKT/mTOR signalling pathway. }\end{array}$ & [75] \\
\hline MiR-21 & $\uparrow$ & $\uparrow$ & - & $\uparrow$ & $\begin{array}{l}\text { Different targets } \\
\text { engaged in each cell } \\
\text { type and at each time } \\
\text { point }\end{array}$ & $\begin{array}{l}\text { As the one of the master regulators of innate immunity, miR-21 plays a myriad of roles in } \\
\text { various cellular processes via regulating genes involved in signalling pathways, such as } \\
\text { p53, FOXO1, TGF- } \alpha \text {, apoptosis (PDCD4),P13K/Akt/mTOR, VEGF, and NF- } \alpha \text { B }\end{array}$ & [69] \\
\hline MiR-22 & $\uparrow$ & - & $\downarrow$ & - & CD147, YWHAZ & $\begin{array}{c}\text { Inhibits hepatocellular carcinoma cell invasion, migration, and proliferation, miR-22 } \\
\text { downregulation predicts poor survival. }\end{array}$ & {$[76,77]$} \\
\hline MiR-223 & $\uparrow$ & - & $\downarrow$ & - & $\begin{array}{l}\text { Ras-related protein } \\
\quad \text { Rab-1 (Rab1) }\end{array}$ & $\begin{array}{c}\text { May promote apoptosis and suppress cell growth through Rab1-mediated mTOR } \\
\text { activation in hepatocellular carcinoma cells. In addition, miR-223 is a biomarker of acute } \\
\text { and chronic liver injury }\end{array}$ & {$[78,79]$} \\
\hline MiR-27 & $\uparrow$ & - & $\downarrow$ & $\uparrow$ & $\begin{array}{l}\text { GATA3, c-Rel, Smad2, } \\
\text { Smad3, lncRNA-CIR }\end{array}$ & $\begin{array}{l}\text { MiR-27 plays the important roles for safeguarding Treg-mediated } \\
\text { immunological tolerance }\end{array}$ & {$[70,80]$} \\
\hline MiR-30 & $\uparrow$ & $\uparrow$ & $\downarrow$ & $\downarrow$ & $\begin{array}{l}\text { MyD88, lncRNA } \\
\text { n379519, lncRNA } \\
\text { CNALPTC1 }\end{array}$ & $\begin{array}{l}\text { Inhibiting cytokine expression and TLR/MyD88 activation in THP-1 cells during } \\
\qquad \begin{array}{c}\text { Mycobacterium tuberculosis } \\
\text { H37Rv infection }\end{array}\end{array}$ & {$[62,81]$} \\
\hline MiR-339 & $\uparrow$ & $\downarrow$ & - & $\uparrow$ & Skp2 & Binding to the $3^{\prime}$-UTR of Skp2 mRNA to inhibit the lung cancer cells proliferation & [82] \\
\hline
\end{tabular}


Table 3. Cont.

\begin{tabular}{|c|c|c|c|c|c|c|c|}
\hline \multirow{3}{*}{ MiRNA } & \multicolumn{4}{|c|}{ Expression Level } & \multirow{3}{*}{ Target } & \multirow{3}{*}{ Biological Function } & \multirow{3}{*}{ Ref. } \\
\hline & \multirow{2}{*}{ Sheep Gut } & \multicolumn{3}{|c|}{ Mouse } & & & \\
\hline & & Macrophage & Liver & Serum & & & \\
\hline MiR-345 & $\uparrow$ & - & $\uparrow$ & $\downarrow$ & AKT2 & $\begin{array}{l}\text { Regulates the cell cycle, apoptosis, and proliferation of acute myeloid leukaemia cells by } \\
\text { targeting AKT2 }\end{array}$ & [83] \\
\hline MiR-365 & $\uparrow$ & - & $\uparrow$ & $\uparrow$ & LncRNA MT1DP, Timp3 & $\begin{array}{l}\text { The lncRNA MT1DP exacerbates cadmium-induced oxidative stress by suppressing the } \\
\text { function of Nrf2 acting as ceRNA of miR-365. Then, miR-365 promotes diabetic } \\
\text { retinopathy through inhibiting lncRNA Timp3 increasing oxidative stress }\end{array}$ & {$[63,84]$} \\
\hline MiR-378 & $\uparrow$ & $\uparrow$ & $\uparrow$ & - & IRG1, lncGAPLINC & $\begin{array}{l}\text { Acts as a prognostic marker and inhibits epithelial-mesenchymal transition in human } \\
\text { glioma and acts as a molecular sponge of lncGAPLINC to stimulate gastric cancer } \\
\text { cell proliferation }\end{array}$ & {$[64,85]$} \\
\hline MiR-449 & $\uparrow$ & - & $\downarrow$ & - & LncARSR & $\begin{array}{l}\text { LncARSR is competitively binding to miR- } 449 \text { and thereby promoting sunitinib resistance } \\
\text { in renal cancer }\end{array}$ & [65] \\
\hline MiR-542 & $\uparrow$ & - & - & $\downarrow$ & SMAD & $\begin{array}{l}\text { After activation of SMAD2/3 phosphorylation and the promotion of mitochondrial } \\
\text { dysfunction, upregulated miR-542-3p/5p may reduce muscle atrophy in intensive care } \\
\text { of patients }\end{array}$ & [86] \\
\hline MiR-877 & $\uparrow$ & - & - & $\downarrow$ & $\begin{array}{l}\text { Cyclin-dependent } \\
\text { kinase } 14\end{array}$ & $\begin{array}{l}\text { Suppresses cell migration, invasion, and growth, and predicts prognosis in hepatocellular } \\
\text { carcinoma }\end{array}$ & [66] \\
\hline MiR-99 & $\uparrow$ & $\uparrow$ & - & - & SMARCA5 & $\begin{array}{l}\begin{array}{l}\text { Regulates Mycoplasma gallisepticum (HS strain) infection by suppressing cell proliferation } \\
\text { in chickens }\end{array} \\
\text { che }\end{array}$ & [87] \\
\hline MiR-124 & $\uparrow$ & - & - & $\downarrow$ & $\begin{array}{l}\text { LncHOTAIR, } \\
\text { lncMALAT1, circMMP9 }\end{array}$ & $\begin{array}{l}\text { LncHOTAIR sponged miRNA-124 to promote renal cell carcinoma malignancy through } \\
\text { alpha-2,8-sialyltransferase } 4 \text {. LncRNA MALAT1 acts as a ceRNA to control } \\
\text { amadori-glycated albumin-induced MCP-1 expression in retinal microglia through a } \\
\text { miRNA-124-dependent mechanism }\end{array}$ & [88-90] \\
\hline MiR-130 & $\uparrow$ & - & - & $\downarrow$ & LncMRPL39 & $\begin{array}{l}\text { LncMRPL39 inhibits gastric cancer progression and proliferation by directly binding to } \\
\qquad \mathrm{miR}-130\end{array}$ & [67] \\
\hline MiR-16 & $\uparrow$ & $\downarrow$ & & & LncDleu2 & $\begin{array}{c}\text { LncDleu2 influences the invasion, migration, and proliferation of laryngeal cancer cells } \\
\text { via miR-16 }\end{array}$ & {$[68]$} \\
\hline
\end{tabular}

Note: $\uparrow$, upregulated; $\downarrow$, downregulated; -, not detected. 


\section{MiRNAs Mainly Associated with Immune and Pathological Processes during Host Infection with Echinococcus spp.}

The functions and mechanisms of several miRNAs, such as miR-19b (E. granulosus) [91], miR-71 (E. multilocularis) [92], and miRNA-222-3p (E. multilocularis) [93], have been identified. These miRNAs can be used as potential diagnostic markers during infection with Echinococcus spp. In this section, we describe the mechanisms and potential uses of these miRNAs in the diagnosis and treatment of echinococcosis.

\subsection{MiR-71 as an Innate Immune Regulator in Echinococcosis}

Extensive research of miR-71 has been conduced, in particular concerning Echinococcus and echinococcosis, revealing that miR-71 is a conserved miRNA that is widely expressed in parasites. Nematode exosome-derived miR-71 can be internalized by host cells and serve as an innate immune regulator [50], performing a significant role in host-parasite interactions [51]. MiR-71 also functions in E. multilocularis protoscolex development, in which it is differentially expressed at various developmental stages and is found at higher levels in protoscoles without hooks than those with hooks [54]. The Nemo-like kinase gene (nlk) is the target of miR-71, when miR-71 binds with nlk, NLK expression is inhibited [54]. Thus, miR-71 might play an integral part in the development of alveolar Echinococcus [92]. These results lay the groundwork for further exploration into new drugs acting through miR-71 and nlk to treat alveolar echinococcosis. Alveolar Echinococcus-derived miR-71 also participates in regulating the immune process in mouse macrophages [53]. MiR-71 mimic-transfected RAW264.7 cells do not show significantly altered levels of IL-10 when compared with negative control-transfected RAW264.7 cells, which exhibit significantly repressed NO production at $12 \mathrm{~h}$ post-treatment [52]. NO is involved in affecting immunosuppressive anti-parasite immune responses and limiting parasite infection, suggesting that it has essential roles in early and chronic infections of Echinococcus spp. [94]. Some components and molecules, such as crude parasite extracts, a laminated layer, and 14-3-3 proteins, have been identified as being able to inhibit NO release by macrophages [94]. Host macrophages may take up parasite-derived miR-71 that is released into the host microenvironments, body fluids, serum, and plasma. Thus, miR-71 is involved in the regulation of Echinococcus spp. development and function in host macrophages and can be useful for studying host-parasite interactions.

\section{2. miR-19b as an Effective Treatment Biomarker}

A previous study described that miR-19b plays a part in various pathological conditions and diseases, such as fibrogenesis, osteosarcoma, and clear cell renal cell carcinoma [91,95-97]. In cystic echinococcosis, peri-cystic fibrosis is accelerated by hydatid cyst fluid [98]. The expression level of miR-19 is downregulated during the progression of hepatic stellate cell (HSC) activation and, similarly, it is significantly decreased in the patients liver tissues with cystic echinococcosis, and this was also found to be the case in a mouse model of liver fibrosis [98]. Furthermore, miR-19b expression was found to be significantly downregulated in fibrotic liver samples when compared to that in neighboring normal liver tissues, interestingly COL1A1 mRNA expression showed significant-negative correlations with the expression of miR-19b [98]. Hydatid cyst fluid significantly promotes the proliferation of LX-2 cells by accelerating the transition from G0/G1 phase to $S$ phase, increasing the mRNA and protein expression levels of COL3A1, TGF $\beta$ RII, COL1A1, and $\alpha$-SMA, [98]. MiR-19b overexpression in hydatid cyst fluid-treated LX-2 cells leads to the significant suppression of cell proliferation and decreases in T $\beta$ RII, COL1A1 and COL3A mRNA, and protein expression levels by blocking signal transmission in the TGF- $\beta$ pathway delaying, or potentially reversing the progression of fibrosis [98]. Thus, hydatid cyst fluid is involved in the progression of fibrosis via the activation of hepatic stellate cells, and the regulation of miR-19 expression is sectional of the mechanism regulating peri-cystic fibrogenesis in cystic echinococcosis. Previous studies have demonstrated that TGF- $\beta / S$ mad pathway activation is the consequence of infections by E. multilocularis $[99,100]$; the activation of this pathway impacts 
host-parasite interactions, such as fibrogenesis, hepatic (and possibly metacestode) cell proliferation, and immune tolerance mechanisms [98]. These results suggest that E. granulosus can promote fibrosis and restrain liver miR-19 expression by increasing T $\beta$ RII expression, extracellular matrix production, and activating hepatic stellate cells [98]. Furthermore, these results provide new evidence supporting the involvement of miRNAs in regulating fibrosis in infectious diseases. The overexpression of miR-19 in the liver might be an effective treatment biomarker in intermediate hosts that were infected with E. granulosus.

\section{3. miR-222-3p Modulates Macrophage Immunity}

Studies have reported that miR-222-3p is implicated in the regulation of vascular physiology and many malignant inflammatory diseases [93]. During infection, E. multilocularis has been shown to dysregulate the expression of miRNAs in the liver and serum of infected mice [43,60]. For example, mouse miR-222-3p tends to be downregulated and significantly decreased at two months and three months post-infection, respectively, in the spleens of infected mice as compared with control mice [43]. Furthermore, crude E. multilocularis antigens significantly inhibit miR-222-3p expression [6]. Macrophages that were transfected with miR-222-3p inhibitors have been shown to moderately decrease NO secretion, relative to control macrophages. Analysis of transfected cells revealed four key genes implicated in the LPS/TLR4 signalling pathway were found to be significantly down- or unregulated; of which TICAM2, TLR4, and CD14 were upregulated, while AP1 was downregulated [6]. Therefore, miR-222-3p downregulation can modulate macrophage immune functions by regulating NO secretion and the LPS/TLR4 signalling pathway, which potentially contributes to the pathogenesis of alveolar echinococcosis. Thus, miR-222-3p downregulation might be useful as an auxiliary diagnostic marker for alveolar echinococcosis.

\section{Echinococcus miRNA-Related Databases}

Various datasets and software programs have been utilized for predicting and analyzing miRNAs in multiple species. Numerous Echinococcus miRNAs have been identified via various transcriptomic and modern computational approaches. The application of these databases and software programs could effectively accelerate the exploration of Echinococcus miRNA functions and mechanisms (Table 4). The Wellcome Sanger Institute and Sequence Read Archive provide raw genome and miRNA sequencing data, respectively (Chinese Human Genome Centre at Shanghai, and Trust Sanger Institute) [12,14]. Echinococcus miRNAs can be authenticated with miRBase [101] and Rfam [102]. Furthermore, miRanda [103], RNA22 [104], RNAhybrid [105], and TarBase v6.0 [106] have been used for predicting and evaluating the targets of miRNAs.

Table 4. Echinococcus miRNA-Related Databases.

\begin{tabular}{|c|c|c|c|}
\hline Name & Website & Description & Reference \\
\hline $\begin{array}{l}\text { Wellcome Sanger } \\
\text { institute }\end{array}$ & $\begin{array}{l}\text { https://www.sanger.ac.uk/ } \\
\text { resources/downloads/ } \\
\text { helminths/echinococcus- } \\
\text { multilocularis.html }\end{array}$ & $\begin{array}{l}\text { Includes E. multilocularis and E. granulosus } \\
\text { genomes }\end{array}$ & [14] \\
\hline $\begin{array}{l}\text { Sequence Read } \\
\text { Archive }\end{array}$ & $\begin{array}{l}\text { https://www.ncbi.nlm.nih. } \\
\text { gov/sra/?term= } \\
\text { Echinococcus\%20miRNA }\end{array}$ & $\begin{array}{l}\text { Includes Echinococcus miRNA raw sequencing } \\
\text { data obtained by second-generation sequencing }\end{array}$ & {$[12,107,108]$} \\
\hline miRBase & http://www.mirbase.org & $\begin{array}{l}\text { A database of Echinococcus miRNA sequences } \\
\text { and annotations }\end{array}$ & [101] \\
\hline Rfam & $\begin{array}{c}\text { http://rfam.xfam.org/search? } \\
\text { q=Echinococcus }\end{array}$ & $\begin{array}{l}\text { Includes known Echinococcus rRNAs, tRNAs, } \\
\text { snRNAs and mRNAs }\end{array}$ & [102] \\
\hline
\end{tabular}


Table 4. Cont.

\begin{tabular}{cccc}
\hline Name & Website & Description & Reference \\
\hline miRDeep2 & $\begin{array}{c}\text { https://www.osc.edu/book/ } \\
\text { export/html/4389 }\end{array}$ & miRNA prediction & [109] \\
miRanda & $\begin{array}{c}\text { http://www.microrna.org/ } \\
\text { microrna/home.do }\end{array}$ & $\begin{array}{c}\text { Used to predict the target genes of all mature } \\
\text { miRNAs }\end{array}$ \\
\hline RNA22 & https: & Used for target predictions for multiple species & [104] \\
RNAhybrid & $\begin{array}{c}\text { https://bibiserv.cebitec.uni- } \\
\text { bielefeld.de/rnahybrid/ }\end{array}$ & $\begin{array}{c}\text { Used to find the minimum free energy for } \\
\text { hybridization of a long and a short RNA for } \\
\text { predicting miRNA targets }\end{array}$ \\
\hline TarBase v6.0 & $\begin{array}{c}\text { http://diana.imis.athena- } \\
\text { innovation.gr/DianaTools/ } \\
\text { index.php?r=tarbase/index }\end{array}$ & $\begin{array}{c}\text { Includes experimentally verified interactions } \\
\text { between miRNAs and target genes }\end{array}$ \\
\hline
\end{tabular}

\section{Techniques and Methods Used in miRNA Studies in Echinococcus and Echinococcosis}

MiRNA studies in Echinococcus and echinococcosis have primarily explored miRNA identification, functions, and mechanisms. Numerous sequencing, bioinformatic analyses, and experimental verification techniques have been utilized to precisely characterize miRNA expression profiles and function mechanisms.

\subsection{MiRNA Identification}

Sanger sequencing [45], modern sequencing techniques (such as RNA sequencing (RNA-seq)) [1,12,44], and bioinformatic analysis approaches (e.g., self-organizing map analysis) [46] have been used to identify miRNAs in Echinococcus and echinococcosis. Among these methods, modern techniques (e.g., the Illumina Genome Analyzer II for small RNA sequencing) provide a high-throughput approach for the large-scale detection of miRNA expression in Echinococcus and echinococcosis. The validity of the sequencing results and miRNA expression levels can be subsequently verified via Northern blotting [45] and qRT-PCR [12,60]. Bioinformatic analysis, an accurate and convenient approach, is an effective tool that can be used for further verification of new and known miRNAs [46]. For example, a novel deep architecture of SOMs was used to predict novel miRNAs that are based on the complete genome of E. multilocularis without the need for RNA-seq data or target analysis for prediction. In theory, this methodology can be easily adapted and applied to any draft genome [46]. However, in practice, these techniques have some limitations. Sanger sequencing is a first-generation sequencing technique, however it is unsuitable for large-scale sequencing. QRT-PCR demands more advanced experimental techniques, but it has the discommodity of high cost and low throughput. The development of high-throughput sequencing technology and the continual expansion of genome libraries has ushered in recent bioinformatic approaches for miRNA discovery (such as the Megablast algorithm and SOM analysis). Despite these advancements, bioinformatic analyses based on big data can yield false positive results, thus further advancements needs to be made to improve the accuracy of experimental tests and provide the necessary verification for the results of bioinformatic analyses.

\subsection{Verification of the Functions and Exploration of the Mechanisms}

Although many Echinococcus and echinococcosis-related miRNAs have been identified, the functions and mechanisms of action of most are unclear. Loss-of-function (LOF) and gain-of-function (GOF) studies are usually employed to examine gene functions [110]. The in vivo study of miRNA functions in Echinococcus proves difficult under the current achievable experimental conditions. Nonetheless, specific miRNAs from Echinococcus hosts, including miRNAs from Echinococcus itself, have been identified. LOF studies of echinococcosis-related miRNAs can be carried out in host cells, such as hepatic stellate cells [98] and mouse macrophages [53], with inhibitors or siRNAs [6]. In vitro GOF studies of echinococcosis-related miRNAs in host cells have been performed via the transfection of 
gene mimics [98]. Additionally, crude Echinococcus antigens have been used to treat host cells to study miRNAs and changes in the expression levels of their targets [6].

\section{Conclusions}

To date, a series of miRNAs have been identified in Echinococcus spp., but the function and mechanism of most have not been validated. More advanced methods need to be applied to identify effective miRNAs and their functions to deeply understand parasite physiology and to screen for useful diagnostic and treatment targets. As one of the most important hosts of Echinococcus spp. and due to the inadvertent nature of infection to humans, more sensitive and discriminatory diagnostic indicators are needed for human echinococcosis in the early stage of infection. Although recent studies have concentrated on miRNAs in Echinococcus spp. metacestodes, more research should be conducted on non-coding RNAs in adult cestodes and definitive hosts. Several reported functional miRNAs, such as miR-71, miR-19b, and miR-222-3p, have potential applications in the study of host-parasite interactions and as treatment targets in echinococcosis, therefore they should receive the increased attention. However, despite their potential, clinical application of these functional miRNAs is distant. Moreover, the function and mechanism of action of many identified miRNAs remain unknown. Future research should devote ample attention to screening for miRNA-based early diagnostic markers and treatment targets for echinococcosis in hosts.

In addition to miRNAs, other non-coding RNAs, such as lncRNAs and circRNAs, may play regulatory roles in Echinococcus spp. and echinococcosis. Recently, the competing endogenous effect has contributed to our understanding of miRNA regulatory mechanisms at the post-transcriptional level. Protein-coding RNAs, IncRNAs, pseudogenes, and circRNAs act as miRNA sponges. Furthermore, these miRNA sponges interact with each other through shared miRNAs and participate in crosstalk to develop miRNA-mediated interactions or miRNA sponge interaction networks. Therefore, identifying lncRNAs and circRNAs in Echinococcus spp. and echinococcosis is necessary for providing new targets for potential treatment and diagnosis.

Author Contributions: D.Y. structured the text and content; G.Y. reviewed the literature and contributed intellectually; T.Y. generated the figures; Z.H. and Y.Y. wrote the manuscript; D.Y. and T.Y. edited the manuscript. All authors have read and agreed to the published version of the manuscript.

Funding: This research was supported by the Natural Science Foundation of China (grant numbers 31402286, 2015; 31972777, 2019], the Key Project of Sichuan Education Department (035Z1364) and the Double Support Project of Discipline Construction of Sichuan Agricultural University (03572781).

Acknowledgments: We are grateful to the Mingyao Yang and YuanLiangzi Tian for support in revised process. We would also like to thank Yan Fu for guidance and editorial suggestions.

Conflicts of Interest: The authors declare no conflicts of interest.

\section{References}

1. Cucher, M.; Macchiaroli, N.; Kamenetzky, L.; Maldonado, L.; Brehm, K.; Rosenzvit, M.C. High-throughput characterization of Echinococcus spp. metacestode miRNomes. Int. J. Parasitol. 2015, 45, 253-267. [CrossRef]

2. Yan, B.; Liu, X.; Wu, J.; Zhao, S.; Yuan, W.; Wang, B.; Wureli, H.; Tu, C.; Chen, C.; Wang, Y. Genetic Diversity of Echinococcus granulosus Genotype G1 in Xinjiang, Northwest of China. Korean J. Parasitol. 2018, 56, 391-396. [CrossRef]

3. McManus, D.P.; Gray, D.J.; Zhang, W.; Yang, Y. Diagnosis, treatment, and management of echinococcosis. BMJ 2012, 344, e3866. [CrossRef] [PubMed]

4. Monteiro, K.M.; De Carvalho, M.O.; Zaha, A.; Ferreira, H.B. Proteomic analysis of the Echinococcus granulosus metacestode during infection of its intermediate host. Proteomics 2010, 10, 1985-1999. [CrossRef]

5. Zhang, C.; Wang, J.; Lü, G.; Li, J.; Lu, X.; Mantion, G.; Vuitton, D.A.; Wen, H.; Lin, R. Hepatocyte Proliferation/Growth Arrest Balance in the Liver of Mice during E. multilocularis Infection: A Coordinated 3-Stage Course. PLoS ONE 2012, 7, e30127. [CrossRef] [PubMed] 
6. Zheng, Y. Suppression of mouse miRNA-222-3p in response to Echinococcus multilocularis infection. Int. Immunopharmacol. 2018, 64, 252-255. [CrossRef] [PubMed]

7. Craig, P.S.; Hegglin, D.; Lightowlers, M.W.; Torgerson, P.R.; Wang, Q. Echinococcosis: Control and Prevention. Adv. Parasitol. 2017, 96, 55-158.

8. Deplazes, P.; Rinaldi, L.; Rojas, C.A.; Torgerson, P.; Harandi, M.; Romig, T.; Antolova, D.; Schurer, J.; Lahmar, S.; Cringoli, G.; et al. Global Distribution of Alveolar and Cystic Echinococcosis; Elsevier BV: Amsterdam, The Netherlands, 2017; Volume 95, pp. 315-493.

9. Wang, Z.; Wang, X.; Liu, X. Echinococcosis in China, a review of the epidemiology of Echinococcus spp. Ecohealth 2008, 5, 115-126. [PubMed]

10. Giraudoux, P.; Zhao, Y.; Afonso, E.; Yan, H.; Knapp, J.; Rogan, M.T.; Shi, D.; Jia, W.; Craig, P.S. Long-term retrospective assessment of a transmission hotspot for human alveolar echinococcosis in mid-west China. PLOS Neglected Trop. Dis. 2019, 13, e0007701. [CrossRef]

11. Nakao, M.; Lavikainen, A.; Yanagida, T.; Ito, A. Phylogenetic systematics of the genus Echinococcus (Cestoda: Taeniidae). Int. J. Parasitol. 2013, 43, 1017-1029. [CrossRef]

12. Macchiaroli, N.; Cucher, M.; Zarowiecki, M.; Maldonado, L.; Kamenetzky, L.; Rosenzvit, M.C. microRNA profiling in the zoonotic parasite Echinococcus canadensis using a high-throughput approach. Parasit. Vectors 2015, 8, 83. [CrossRef] [PubMed]

13. Lekka, E.; Hall, J. Noncoding RNAs in disease. FEBS Lett. 2018, 592, 2884-2900. [CrossRef] [PubMed]

14. Tsai, I.J.; The Taenia Solium Genome Consortium; Zarowiecki, M.; Holroyd, N.; Garciarrubio, A.; Sánchez-Flores, A.; Brooks, K.L.; Tracey, A.; Bobes, R.J.; Fragoso, G.; et al. The genomes of four tapeworm species reveal adaptations to parasitism. Nature 2013, 496, 57-63. [CrossRef] [PubMed]

15. Zheng, H.; Zhang, W.; Zhang, L.; Zhang, Z.; Li, J.; Lu, G.; Zhu, Y.; Wang, Y.; Huang, Y.; Liu, J.; et al. The genome of the hydatid tapeworm Echinococcus granulosus. Nat. Genet. 2013, 45, 1168-1175. [CrossRef] [PubMed]

16. Bartel, D.P. Metazoan MicroRNAs. Cell 2018, 173, 20-51. [CrossRef] [PubMed]

17. Barbagallo, D.; Vittone, G.; Romani, M.; Purrello, M. Noncoding RNAs in Health and Disease. Int. J. Genom. 2018, 2018, 1-2. [CrossRef]

18. Ancarola, M.E.; Marcilla, A.; Herz, M.; Macchiaroli, N.; Pérez, M.; Asurmendi, S.; Brehm, K.; Poncini, C.; Rosenzvit, M.; Cucher, M. Cestode parasites release extracellular vesicles with microRNAs and immunodiagnostic protein cargo. Int. J. Parasitol. 2017, 47, 675-686. [CrossRef]

19. Yu, A.; Wang, Y.; Yin, J.; Zhang, J.; Cao, S.; Cao, J.; Shen, Y. Microarray analysis of long non-coding RNA expression profiles in monocytic myeloid-derived suppressor cells in Echinococcus granulosus-infected mice. Parasit. Vectors 2018, 11, 327. [CrossRef]

20. Ameres, S.L.; Zamore, P.D. Diversifying microRNA sequence and function. Nat. Rev. Mol. Cell Boil. 2013, 14, 475-488. [CrossRef]

21. Bian, E.-B.; Xiong, Z.-G.; Li, J. New advances of lncRNAs in liver fibrosis, with specific focus on lncRNA-miRNA interactions. J. Cell. Physiol. 2018, 234, 2194-2203. [CrossRef]

22. Zhang, Z.; Yang, T.; Xiao, J. Circular RNAs: Promising Biomarkers for Human Diseases. EBioMedicine 2018, 34, 267-274. [CrossRef] [PubMed]

23. Macchiaroli, N.; Maldonado, L.L.; Zarowiecki, M.; Cucher, M.; Gismondi, M.I.; Kamenetzky, L.; Rosenzvit, M.C. Genome-wide identification of microRNA targets in the neglected disease pathogens of the genus Echinococcus. Mol. Biochem. Parasitol. 2017, 214, 91-100. [CrossRef] [PubMed]

24. Judice, C.C.; Bourgard, C.; Kayano, A.C.A.V.; Albrecht, L.; Costa, F.T.M. MicroRNAs in the Host-Apicomplexan Parasites Interactions: A Review of Immunopathological Aspects. Front. Microbiol. 2016, 6, 499. [CrossRef]

25. Carrière, J.; Barnich, N.; Nguyen, H.T.T. Exosomes: From Functions in Host-Pathogen Interactions and Immunity to Diagnostic and Therapeutic Opportunities. Rev. Physiol. Biochem. Pharmacol. 2016, 172, $39-75$. [PubMed]

26. Cai, P.; Gobert, G.N.; McManus, D.P.; Information, P.E.K.F.C. MicroRNAs in Parasitic Helminthiases: Current Status and Future Perspectives. Trends Parasitol. 2016, 32, 71-86. [CrossRef] [PubMed]

27. Huang, Y. The novel regulatory role of lncRNA-miRNA-mRNA axis in cardiovascular diseases. J. Cell. Mol. Med. 2018, 22, 5768-5775. [CrossRef] 
28. Zampetaki, A.; Albrecht, A.; Steinhofel, K. Long Non-coding RNA Structure and Function: Is There a Link? Front. Physiol. 2018, 9, 9. [CrossRef]

29. Yue, Y.; Guo, T.; Yuan, C.; Liu, J.; Guo, J.; Feng, R.; Niu, C.; Sun, X.; Yang, B. Integrated analysis of the roles of long noncoding RNA and coding RNA expression in sheep (Ovis aries) skin during initiation of secondary hair follicle. PLoS ONE 2016, 11, e0156890. [CrossRef]

30. Zhan, S.; Dong, Y.; Zhao, W.; Guo, J.; Zhong, T.; Wang, L.; Li, L.; Zhang, H. Genome-wide identification and characterization of long non-coding RNAs in developmental skeletal muscle of fetal goat. BMC Genom. 2016, 17, 666. [CrossRef]

31. Kern, C.; Wang, Y.; Chitwood, J.; Korf, I.; Delany, M.; Cheng, H.; Medrano, J.F.; Van Eenennaam, A.L.; Ernst, C.; Ross, P.; et al. Genome-wide identification of tissue-specific long non-coding RNA in three farm animal species. BMC Genom. 2018, 19, 684. [CrossRef]

32. Gao, P.F.; Guo, X.H.; Du, M.; Cao, G.Q.; Yang, Q.C.; Pu, Z.D.; Wang, Z.Y.; Zhang, Q.; Li, M.; Jin, Y.S.; et al. LncRNA profiling of skeletal muscles in Large White pigs and Mashen pigs during development. J. Anim. Sci. 2017, 95, 4239-4250. [CrossRef] [PubMed]

33. Scott, E.Y.; Mansour, T.; Bellone, R.R.; Brown, C.T.; Mienaltowski, M.J.; Penedo, M.C.; Ross, P.J.; Valberg, S.J.; Murray, J.D.; Finno, C.J. Identification of long non-coding RNA in the horse transcriptome. BMC Genom. 2017, 18, 511. [CrossRef] [PubMed]

34. Zhao, Z.; Bai, J.; Wu, A.; Wang, Y.; Zhang, J.; Wang, Z.; Li, Y.; Xu, J.; Li, X. Co-LncRNA: Investigating the lncRNA combinatorial effects in GO annotations and KEGG pathways based on human RNA-Seq data. Database 2015, 2015. [CrossRef] [PubMed]

35. Le Béguec, C.; Wucher, V.; Lagoutte, L.; Cadieu, E.; Botherel, N.; Hédan, B.; De Brito, C.; Guillory, A.-S.; André, C.; Derrien, T.; et al. Characterisation and functional predictions of canine long non-coding RNAs. Sci. Rep. 2018, 8, 13444. [CrossRef]

36. Woehle, C.; Kusdian, G.; Radine, C.; Graur, D.; Landan, G.; Gould, S.B. The parasite Trichomonas vaginalis expresses thousands of pseudogenes and long non-coding RNAs independently from functional neighbouring genes. BMC Genom. 2014, 15, 906. [CrossRef]

37. Liu, W.; Huang, L.; Wei, Q.; Zhang, Y.; Zhang, S.; Zhang, W.; Cai, L.; Liang, S. Microarray analysis of long non-coding RNA expression profiles uncovers a Toxoplasma-induced negative regulation of host immune signaling. Parasit. Vectors 2018, 11, 174. [CrossRef]

38. Kim, V.N. MicroRNA biogenesis: Coordinated cropping and dicing. Nat. Rev. Mol. Cell Boil. 2005, 6, 376-385. [CrossRef]

39. Kwak, P.B.; Tomari, Y. The N domain of Argonaute drives duplex unwinding during RISC assembly. Nat. Struct. Mol. Boil. 2012, 19, 145-151. [CrossRef]

40. Cheloufi, S.; Dos Santos, C.O.; Chong, M.M.W.; Hannon, G.J. A dicer-independent miRNA biogenesis pathway that requires Ago catalysis. Nature 2010, 465, 584-589. [CrossRef]

41. Du, W.W.; Zhang, C.; Yang, W.; Yong, T.; Awan, F.M.; Yang, B.B. Identifying and Characterizing circRNA-Protein Interaction. Theranostics 2017, 7, 4183-4191. [CrossRef]

42. Zhang, X.; Wang, W.; Zhu, W.; Dong, J.; Cheng, Y.; Yin, Z.; Shen, F. Mechanisms and Functions of Long Non-Coding RNAs at Multiple Regulatory Levels. Int. J. Mol. Sci. 2019, 20, 5573. [CrossRef] [PubMed]

43. Guo, X.; Zheng, Y. Expression profiling of circulating miRNAs in mouse serum in response to Echinococcus multilocularis infection. Parasitology 2017, 144, 1079-1087. [CrossRef] [PubMed]

44. Bai, Y.; Zhang, Z.; Jin, L.; Kang, H.; Zhu, Y.; Zhang, L.; Li, X.; Ma, F.; Zhao, L.; Shi, B.; et al. Genome-wide sequencing of small RNAs reveals a tissue-specific loss of conserved microRNA families in Echinococcus granulosus. BMC Genom. 2014, 15, 736. [CrossRef] [PubMed]

45. Cucher, M.; Prada, L.; Mourglia-Ettlin, G.; Dematteis, S.; Camicia, F.; Asurmendi, S.; Rosenzvit, M. Identification of Echinococcus granulosus microRNAs and their expression in different life cycle stages and parasite genotypes. Int. J. Parasitol. 2011, 41, 439-448. [CrossRef]

46. Kamenetzky, L.; Stegmayer, G.; Maldonado, L.; Macchiaroli, N.; Yones, C.; Milone, D. MicroRNA discovery in the human parasite Echinococcus multilocularis from genome-wide data. Genomics 2016, 107, 274-280. [CrossRef]

47. Wang, Z.R.; Bo, X.W.; Zhang, Y.Y.; MA, X.; Lu, P.P.; Xu, M.F.; Meng, J.M. microRNA profile analyses of the protoscoleces in Echinococcus granulosus. Acta Vet. et Zootech. Sin. 2018, 49, 2477-2485. 
48. Jin, X.; Lu, L.; Su, H.; Lou, Z.; Wang, F.; Zheng, Y.; Xu, G.-T. Comparative analysis of known miRNAs across platyhelminths. FEBS J. 2013, 280, 3944-3951. [CrossRef] [PubMed]

49. Mortezaei, S.; Afgar, A.; Mohammadi, M.A.; Mousavi, S.M.; Sadeghi, B.; Harandi, M.F. The effect of albendazole sulfoxide on the expression of miR-61 and let-7 in different in vitro developmental stages of Echinococcus granulosus. Acta Trop. 2019, 195, 97-102. [CrossRef]

50. Buck, A.H.; Coakley, G.; Simbari, F.; McSorley, H.J.; Quintana, J.F.; Le Bihan, T.; Kumar, S.; Abreu-Goodger, C.; Lear, M.; Harcus, Y.; et al. Exosomes secreted by nematode parasites transfer small RNAs to mammalian cells and modulate innate immunity. Nat. Commun. 2014, 5, 5488. [CrossRef]

51. Quintana, J.F.; Makepeace, B.L.; Babayan, S.A.; Ivens, A.; Pfarr, K.M.; Blaxter, M.; Debrah, A.; Wanji, S.; Ngangyung, H.F.; Bah, G.S.; et al. Extracellular Onchocerca-derived small RNAs in host nodules and blood. Parasit. Vectors 2015, 8, 58. [CrossRef]

52. Juvvuna, P.K.; Khandelia, P.; Lee, L.M.; Makeyev, E.V. Argonaute identity defines the length of mature mammalian microRNAs. Nucleic Acids Res. 2012, 40, 6808-6820. [CrossRef] [PubMed]

53. Zheng, Y.; Guo, X.; He, W.; Shao, Z.; Zhang, X.; Yang, J.; Shen, Y.; Luo, X.; Cao, J. Effects of Echinococcus multilocularis miR-71 mimics on murine macrophage RAW264.7 cells. Int. Immunopharmacol. 2016, 34, 259-262. [CrossRef]

54. Guo, X.; Zhang, X.; Yang, J.; Jin, X.; Ding, J.; Xiang, H.; Ayaz, M.; Luo, X.; Zheng, Y. Suppression of nemo-like kinase by miR-71 in Echinococcus multilocularis. Exp. Parasitol. 2017, 183, 1-5. [CrossRef]

55. Zheng, Y.; Cai, X.; Bradley, J.E. microRNAs in parasites and parasite infection. RNA Boil. 2013, 10, 371-379. [CrossRef] [PubMed]

56. Guo, X.; Zheng, Y. MicroRNA expression profile in RAW264.7 macrophage cells exposed to Echinococcus multilocularis metacestodes. Parasitology 2018, 145, 416-423. [CrossRef] [PubMed]

57. Jiang, S.; Li, X.; Wang, X.; Ban, Q.; Hui, W.; Jia, B. MicroRNA profiling of the intestinal tissue of Kazakh sheep after experimental Echinococcus granulosus infection, using a high-throughput approach. Parasite 2016, 23, 23. [CrossRef]

58. Schmid, M.; Zimara, N.; Wege, A.K.; Ritter, U. Myeloid-derived suppressor cell functionality and interaction with Leishmania major parasites differ in C57BL/6 and BALB/c mice. Eur. J. Immunol. 2014, 44, 3295-3306. [CrossRef]

59. Pan, W.; Zhou, H.-J.; Shen, Y.-J.; Wang, Y.; Xu, Y.-X.; Hu, Y.; Jiang, Y.-Y.; Yuan, Z.-Y.; Ugwu, C.E.; Cao, J.-P. Surveillance on the Status of Immune Cells after Echinnococcus granulosus Protoscoleces Infection in Balb/c Mice. PLoS ONE 2013, 8, e59746. [CrossRef]

60. Jin, X.; Guo, X.; Zhu, N.; Ayaz, M.; Zheng, Y. miRNA profiling in the mice in response to Echinococcus multilocularis infection. Acta Trop. 2017, 166, 39-44. [CrossRef]

61. Jiang, M.-M.; Mai, Z.-T.; Wan, S.-Z.; Chi, Y.-M.; Zhang, X.; Sun, B.-H.; Di, Q.-G. Microarray profiles reveal that circular RNA hsa_circ_0007385 functions as an oncogene in non-small cell lung cancer tumorigenesis. J. Cancer Res. Clin. Oncol. 2018, 144, 667-674. [CrossRef]

62. Wang, X.; Yong, C.; Yu, K.; Yu, R.; Zhang, R.; Yu, L.; Li, S.; Cai, S. Long Noncoding RNA (lncRNA) n379519 Promotes Cardiac Fibrosis in Post-Infarct Myocardium by Targeting miR-30. Med Sci. Monit. 2018, 24, 3958-3965. [CrossRef] [PubMed]

63. Gao, M.; Li, C.; Xu, M.; Liu, Y.; Cong, M.; Liu, S. LncRNA MT1DP Aggravates Cadmium-Induced Oxidative Stress by Repressing the Function of Nrf2 and is Dependent on Interaction with miR-365. Adv. Sci. 2018, 5, 1800087. [CrossRef] [PubMed]

64. Diao, L.; Wang, S.; Sun, Z. Long noncoding RNA GAPLINC promotes gastric cancer cell proliferation by acting as a molecular sponge of miR-378 to modulate MAPK1 expression. OncoTargets Ther. 2018, 11, 2797-2804. [CrossRef] [PubMed]

65. Qu, L.; Ding, J.; Chen, C.; Wu, Z.-J.; Liu, B.; Gao, Y.; Chen, W.; Liu, F.; Sun, W.; Li, X.-F.; et al. Exosome-Transmitted lncARSR Promotes Sunitinib Resistance in Renal Cancer by Acting as a Competing Endogenous RNA. Cancer Cell 2016, 29, 653-668. [CrossRef]

66. Yan, T.H.; Qiu, C.; Sun, J.; Li, W.H. MiR-877-5p suppresses cell growth, migration and invasion by targeting cyclin dependent kinase 14 and predicts prognosis in hepatocellular carcinoma. Eur. Rev. Med. Pharmacol. Sci. 2018, 22, 3038-3046.

67. Yu, M.J.; Zhao, N.; Shen, H.; Wang, H. Long Noncoding RNA MRPL39 Inhibits Gastric Cancer Proliferation and Progression by Directly Targeting miR-130. Genet. Test. Mol. Biomark. 2018, 22, 656-663. [CrossRef] 
68. Xie, Z.-Z.; Xiao, Z.-C.; Song, Y.-X.; Li, W.; Tan, G.-L. Long non-coding RNA Dleu2 affects proliferation, migration and invasion ability of laryngeal carcinoma cells through triggering miR-16-1 pathway. Eur. Rev. Med Pharmacol. Sci. 2018, 22, 1963-1970.

69. Momen-Heravi, F.; Bala, S. miRNA regulation of innate immunity. J. Leukoc. Boil. 2018, 103, $1205-1217$. [CrossRef]

70. Cruz, L.O.; Hashemifar, S.S.; Wu, C.-J.; Cho, S.; Nguyen, D.T.; Lin, L.-L.; Khan, A.A.; Lu, L.-F. Excessive expression of miR-27 impairs Treg-mediated immunological tolerance. J. Clin. Investig. 2017, 127, 530-542. [CrossRef]

71. Liu, H.; Chen, N.; Bi, J.; Han, J.; Yang, M.; Dong, W.; Lin, T.; Huang, J. Circular RNA circUBXN7 represses cell growth and invasion by sponging miR-1247-3p to enhance B4GALT3 expression in bladder cancer. Aging 2018, 10, 2606-2623. [CrossRef]

72. Yang, J.; Liu, Q.; Cao, S.; Xu, T.; Li, X.; Zhou, D.; Pan, L.; Li, C.; Huang, C.; Meng, X.; et al. MicroRNA-145 increases the apoptosis of activated hepatic stellate cells induced by TRAIL through NF-kappaB signaling pathway. Front. Pharmacol. 2017, 8, 980. [CrossRef] [PubMed]

73. Ghorbani, S.; Talebi, F.; Chan, W.F.; Masoumi, F.; Vojgani, M.; Power, C.; Noorbakhsh, F. MicroRNA-181 Variants Regulate T Cell Phenotype in the Context of Autoimmune Neuroinflammation. Front. Immunol. 2017, 8, 758. [CrossRef] [PubMed]

74. Gantier, M.P. X-chromosome-encoded microRNA-19 and -18 are possible modulators of female immunity. BioEssays 2013, 35, 671. [CrossRef] [PubMed]

75. He, W.; Cheng, Y. Inhibition of miR-20 promotes proliferation and autophagy in articular chondrocytes by PI3K/AKT/mTOR signaling pathway. Biomed. Pharmacother. 2018, 97, 607-615. [CrossRef]

76. Luo, L.-J.; Zhang, L.-P.; Duan, C.-Y.; Wang, B.; He, N.-N.; Abulimiti, P.; Lin, Y. The inhibition role of miR-22 in hepatocellular carcinoma cell migration and invasion via targeting CD147. Cancer Cell Int. 2017, 17, 17. [CrossRef]

77. Chen, M.; Hu, W.; Xiong, C.-L.; Qu, Z.; Yin, C.-Q.; Wang, Y.-H.; Luo, C.-L.; Guan, Q.; Yuan, C.-H.; Wang, F.-B. miR-22 targets YWHAZ to inhibit metastasis of hepatocellular carcinoma and its down-regulation predicts a poor survival. Oncotarget 2016, 7, 80751-80764. [CrossRef]

78. Dong, Z.; Qi, R.; Guo, X.; Zhao, X.; Li, Y.; Zeng, Z.; Bai, W.; Chang, X.; Hao, L.; Chen, Y.; et al. MiR-223 modulates hepatocellular carcinoma cell proliferation through promoting apoptosis via the Rab1-mediated mTOR activation. Biochem. Biophys. Res. Commun. 2017, 483, 630-637. [CrossRef]

79. Schueller, F.; Roy, S.; Loosen, S.H.; Alder, J.; Koppe, C.; Schneider, A.T.; Wandrer, F.; Bantel, H.; Vucur, M.; Mi, Q.-S.; et al. miR-223 represents a biomarker in acute and chronic liver injury. Clin. Sci. 2017, 131, 1971-1987. [CrossRef]

80. Li, Y.-F.; Li, S.-H.; Liu, Y.; Luo, Y.-T. Long Noncoding RNA CIR Promotes Chondrocyte Extracellular Matrix Degradation in Osteoarthritis by Acting as a Sponge For Mir-27b. Cell. Physiol. Biochem. 2017, 43, 602-610. [CrossRef]

81. Wu, Y.; Sun, Q.; Dai, L. Immune regulation of miR-30 on the Mycobacterium tuberculosis-induced TLR/MyD88 signaling pathway in THP-1 cells. Exp. Ther. Med. 2017, 14, 3299-3303. [CrossRef]

82. Ren, H.; Zhang, Y.; Zhu, H. MiR-339 depresses cell proliferation via directly targeting S-phase kinase-associated protein 2 mRNA in lung cancer. Thorac. Cancer 2018, 9, 408-414. [CrossRef] [PubMed]

83. Ying, X.; Zhang, W.; Fang, M.; Zhang, W.; Wang, C.; Han, L. miR-345-5p regulates proliferation, cell cycle, and apoptosis of acute myeloid leukemia cells by targeting AKT2. J. Cell. Biochem. 2018, 120, 1620-1629. [CrossRef] [PubMed]

84. Wang, J.; Zhang, J.; Chen, X.; Yang, Y.; Wang, F.; Li, W.; Awuti, M.; Sun, Y.; Lian, C.; Li, Z.; et al. miR-365 promotes diabetic retinopathy through inhibiting Timp3 and increasing oxidative stress. Exp. Eye Res. 2018, 168, 89-99. [CrossRef] [PubMed]

85. Shi, H.-Z.; Wang, D.; Sun, X.-N.; Sheng, L. MicroRNA-378 acts as a prognosis marker and inhibits cell migration, invasion and epithelial-mesenchymal transition in human glioma by targeting IRG1. Eur. Rev. Med Pharmacol. Sci. 2018, 22, 3837-3846. [PubMed]

86. Garros, R.F.; Paul, R.; Connolly, M.; Lewis, A.; Garfield, B.E.; Natanek, S.A.; Bloch, S.; Mouly, V.; Griffiths, M.J.; Polkey, M.I.; et al. MicroRNA-542 Promotes Mitochondrial Dysfunction and SMAD Activity and Is Elevated in Intensive Care Unit-acquired Weakness. Am. J. Respir. Crit. Care Med. 2017, 196, 1422-1433. [CrossRef] 
87. Zhao, Y.; Wang, Z.; Hou, Y.; Zhang, K.; Peng, X. gga-miR-99a targets SMARCA5 to regulate Mycoplasma gallisepticum (HS strain) infection by depressing cell proliferation in chicken. Gene 2017, 627, $239-247$. [CrossRef]

88. Pan, Y.; Wu, Y.; Hu, J.; Shan, Y.; Ma, J.; Ma, H.; Qi, X.; Jia, L. Long noncoding RNA HOTAIR promotes renal cell carcinoma malignancy through alpha-2, 8-sialyltransferase 4 by sponging microRNA-124. Cell Prolif. 2018, 51, e12507. [CrossRef]

89. Dong, N.; Xu, B.; Shi, H. Long noncoding RNA MALAT1 acts as a competing endogenous RNA to regulate Amadori-glycated albumin-induced MCP-1 expression in retinal microglia by a microRNA-124-dependent mechanism. Inflamm. Res. 2018, 67, 913-925. [CrossRef]

90. Wang, R.; Zhang, S.; Chen, X.; Li, N.; Li, J.; Jia, R.; Pan, Y.; Liang, H. EIF4A3-induced circular RNA MMP9 (circMMP9) acts as a sponge of miR-124 and promotes glioblastoma multiforme cell tumorigenesis. Mol. Cancer 2018, 17, 166. [CrossRef]

91. Lakner, A.M.; Steuerwald, N.M.; Walling, T.L.; Ghosh, S.; Li, T.; McKillop, I.H.; Russo, M.W.; Bonkovsky, H.L.; Schrum, L.W. Inhibitory effects of microRNA 19b in hepatic stellate cell-mediated fibrogenesis. Hepatol. 2012, 56, 300-310. [CrossRef]

92. Xueyong, Z. Primary Studies on the emu-miR-71 as Inhibiting Molecule of the Potential Drug Target Nemo-Like Kinase in Echinococcus Multilocularis Metacestode; Lanzhou Veterinary Research Institute: Lanzhou, China, 2015.

93. Song, J.; Ouyang, Y.; Che, J.; Li, X.; Zhao, Y.; Yang, K.; Zhao, X.; Chen, Y.; Fan, C.; Yuan, W. Potential Value of miR-221/222 as Diagnostic, Prognostic, and Therapeutic Biomarkers for Diseases. Front. Immunol. 2017, 8, 29. [CrossRef] [PubMed]

94. Zheng, Y. Strategies of Echinococcus species responses to immune attacks: Implications for therapeutic tool development. Int. Immunopharmacol. 2013, 17, 495-501. [CrossRef] [PubMed]

95. Wang, L.; Yang, G.; Zhao, D.; Wang, J.; Bai, Y.; Peng, Q.; Wang, H.; Fang, R.; Chen, G.; Wang, Z.; et al. CD103-positive CSC exosome promotes EMT of clear cell renal cell carcinoma: Role of remote MiR-19b-3p. Mol. Cancer 2019, 18, 86. [CrossRef] [PubMed]

96. Du, Y.-X.; Guo, L.-X.; Pan, H.-S.; Liang, Y.-M.; Li, X. Circ_ANKIB1 stabilizes the regulation of miR-19b on SOCS3/STAT3 pathway to promote osteosarcoma cell growth and invasion. Hum. Cell 2019, 33, 252-260. [CrossRef] [PubMed]

97. Pan, L.; Liu, D.; Zhao, L.; Wang, L.; Xin, M.; Li, X. Long noncoding RNA MALAT1 alleviates lipopolysaccharide-induced inflammatory injury by upregulating microRNA-19b in murine chondrogenic ATDC5 cells. J. Cell. Biochem. 2018, 119, 10165-10175. [CrossRef] [PubMed]

98. Zhang, C.; Wang, L.; Ali, T.; Li, L.; Bi, X.; Wang, J.; Lu, G.; Shao, Y.; Vuitton, D.A.; Wen, H.; et al. Hydatid cyst fluid promotes peri-cystic fibrosis in cystic echinococcosis by suppressing miR-19 expression. Parasit. Vectors 2016, 9, 278. [CrossRef] [PubMed]

99. Wang, J.; Zhang, C.; Wei, X.; Blagosklonov, O.; Lv, G.; Lu, X.; Mantion, G.; Vuitton, D.A.; Wen, H.; Lin, R. TGF-beta and TGF-beta/Smad signaling in the interactions between Echinococcus multilocularis and its hosts. PLoS ONE 2013, 8, e55379.

100. Wang, J.; Lin, R.; Zhang, W.; Li, L.; Gottstein, B.; Blagosklonov, O.; Lü, G.; Zhang, C.; Lu, X.; Vuitton, D.A.; et al. Transcriptional Profiles of Cytokine/Chemokine Factors of Immune Cell-Homing to the Parasitic Lesions: A Comprehensive One-Year Course Study in the Liver of E. multilocularis-Infected Mice. PLoS ONE 2014, 9, e91638. [CrossRef]

101. Kozomara, A.; Birgaoanu, M.; Griffiths-Jones, S. miRBase: From microRNA sequences to function. Nucleic Acids Res. 2019, 47, D155-D162. [CrossRef]

102. Nawrocki, E.P.; Burge, S.W.; Bateman, A.; Daub, J.; Eberhardt, R.Y.; Eddy, S.R.; Floden, E.W.; Gardner, P.P.; Jones, T.A.; Tate, J.; et al. Rfam 12.0: Updates to the RNA families database. Nucleic Acids Res. 2015, 43, D130-D137. [CrossRef]

103. Betel, D.; Koppal, A.; Agius, P.; Sander, C.; Leslie, C. Comprehensive modeling of microRNA targets predicts functional non-conserved and non-canonical sites. Genome Boil. 2010, 11, R90. [CrossRef] [PubMed]

104. Miranda, K.C.; Huynh, T.; Tay, Y.; Ang, Y.-S.; Tam, W.-L.; Thomson, A.M.; Lim, B.; Rigoutsos, I. A Pattern-Based Method for the Identification of MicroRNA Binding Sites and Their Corresponding Heteroduplexes. Cell 2006, 126, 1203-1217. [CrossRef] [PubMed]

105. Krüger, J.; Rehmsmeier, M. RNAhybrid: microRNA target prediction easy, fast and flexible. Nucleic Acids Res. 2006, 34, W451-W454. [CrossRef] [PubMed] 
106. Vlachos, I.S.; Paraskevopoulou, M.D.; Karagkouni, D.; Georgakilas, G.; Vergoulis, T.; Kanellos, I.; Anastasopoulos, I.L.; Maniou, S.; Karathanou, K.; Kalfakakou, D.; et al. DIANA-TarBase v7.0: Indexing more than half a million experimentally supported miRNA:mRNA interactions. Nucleic Acids Res. 2015, 43, D153-D159. [CrossRef] [PubMed]

107. Liu, S.; Zhou, X.; Hao, L.; Piao, X.; Hou, N.; Chen, Q. Genome-Wide Transcriptome Analysis Reveals Extensive Alternative Splicing Events in the Protoscoleces of Echinococcus granulosus and Echinococcus multilocularis. Front Microbiol. 2017, 8, 929. [CrossRef] [PubMed]

108. Shanghai Chinese Human Genome Center. Echinococcus Granulosus Small RNA Transcriptome; Yun Bai: Shanghai, China, 2013.

109. Friedlander, M.R.; Mackowiak, S.D.; Li, N.; Chen, W.; Rajewsky, N. miRDeep2 accurately identifies known and hundreds of novel microRNA genes in seven animal clades. Nucleic Acids Res. 2012, 40,37-52. [CrossRef] [PubMed]

110. Roote, J.; Prokop, A. How to Design a Genetic Mating Scheme: A Basic Training Package for Drosophila Genetics. G3 Genes Genomes Genet. 2013, 3, 353-358.

(C) 2020 by the authors. Licensee MDPI, Basel, Switzerland. This article is an open access article distributed under the terms and conditions of the Creative Commons Attribution (CC BY) license (http://creativecommons.org/licenses/by/4.0/). 